\title{
Faktor-Faktor yang Mempengaruhi Kinerja Karyawan pada PT. Jocelyn Anugrah Jaya
}

\author{
Septiana dan Oey Hannes Widjaja \\ Program Studi Manajemen Fakultas Ekonomi \& Bisnis \\ Universitas Tarumanagara \\ Email: septiana.115179106@stu.untar.ac.id
}

\begin{abstract}
This study aims to analyze the effect of work stress, workload and work environment on employee performance at PT. Jocelyn Anugrah Jaya. This research was conducted with a probability sampling method with a simple random sampling type. Researchers distributed questionnaires to 100 employees of PT Jocelyn Anugrah Jaya. Data analysis using multiple regression analysis with the help of SPSS ver. 25. The results of the analysis concluded that work stress has a significant negative effect on employee performance while the workload and work environment have a positive effect on the performance of employees of PT. Jocelyn Anugrah Jaya
\end{abstract}

Keywords: Work stress, workload, work environment and performance

Abstrak: Penelitian ini bertujuan untuk menganalisis pengaruh stres kerja, beban kerja dan lingkungan kerja terhadap kinerja karyawan pada PT. Jocelyn Anugrah Jaya. Penelitian ini dilakukan dengan metode probability sampling dengan jenis simple random sampling. Peneliti menyebarkan kuesioner kepada 100 karyawan PT Jocelyn Anugrah Jaya. Analisis data menggunakan analisis regresi ganda dengan bantu SPSS ver. 25. Hasil analisis menyimpulkan bahwa stres kerja berpengaruh negatif signifikan terhadap kinerja karyawan sedangkan beban kerja dan lingkungan kerja berpengaruh positif terhadap kinerja karyawan PT. Jocelyn Anugrah Jaya

Kata kunci: stres kerja, beban kerja, lingkungan kerja dan kinerja

\section{LATAR BELAKANG}

Persaingan global saat ini, dunia kerja sangat membutuhkan orang yang biasa berfikir untuk maju, cerdas, inovatif dan mampu berkarya dengan semangat tinggi dalam menghadapi kemajuan zaman.Berbagai organisasi, berusaha meningkatkan kinerja dari seluruh elemen yang ada dalam organisasi dengan tujuan mencapai kelangsungan hidup organisasi.Sumber daya manusia yang dalam hal ini adalah para pegawai pada sebuah organisasi, tentunya berusaha bekerja dengan kemampuan yang mereka miliki agar dapat mencapai kinerja yang diinginkan organisasi tersebut. Rasa aman dan kenyamanan akan suasana kerja mampu mendorong pegawai untuk lebih berdedikasi tinggi dalam menyelesaikan pekerjaan, dan akan membantu pegawai mencapai kinerja yang terbaik.

Sumber daya manusia merupakan komponen utama suatu organisasi yang menjadi perencana dan pelaku aktif dalam setiap aktivitas organisasi. Mereka mempunyai pikiran, perasaan, keinginan, status dan latar belakang pendidikan, usia, jenis kelamin yang heterogen yang dibawa kedalam suatu organisasi sehingga tidak seperti mesin, uang dan material, yang sifatnya pasif dan dapat dikuasai dan diatur sepenuhnya dalam mendukung tercapainya tujuan organisasi. 
Menurut Sedarmayanti (2011:260) mengungkapkan bahwa, kinerja merupakan terjemahan dari prestasi yang berarti hasil kerja seorang pekerja, sebuah proses manajemen atau suatu organisasi secara keseluruhan, dimana hasil kerja tersebut harus dapat ditunjukkan buktinya secara konkrit dan dapat diukur (dibandingkan dengan standar yang telah ditentukan). Usaha untuk meningkatkan kinerja karyawan, diantaranya adalah dengan memperhatikan stres kerja dan beban kerja.Stres dapat menimbulkan dampak yang negatif terhadap keadaan psikologis dan biologis bagi karyawan.Stres merupakan kondisi dinamis dimana seseorang individu dihadapkan dengan kesempatan, keterbatasan atau tuntutan sesuai dengan harapan dari hasil yang ingin dia capai dalam kondisi penting dan tidak menentu.Pengaruh sumbersumber stres kerja terhadap kinerja karyawan yang menunjukkan bahwa individual stres berpengaruh paling dominan terhadap kinerja karyawan. Disisi lain stres kerja dapat dipengaruhi oleh masalah dalam perusahaan, Stress merupakan suatu kondisi keadaan seseorang mengalami, ketegangan karena adanya kondisi yang mempengaruhinya, kondisi tersebut dapat diperoleh dari dalam diri seseorang maupun lingkungan di luar diri seseorang(Septiana, Harini, \& Sudarijati, 2018). Selain stres, faktor lain yang mempengaruhi kinerja karyawan adalah lingkungan kerja. Lingkungan kerja yang baik diharapkan dapat memacu kinerja karyawan yang tinggi. Lingkungan kerja yang baik akan sangat besar pengaruhnya terhadap kinerja karyawan, aspek yang berpengaruh terhadap lingkungan kerja antara lain pengaturan penerangan, tingkat kerja, kebisingan, sirkulasi udara yang baik terutama didalam lingkungan kerja, kebersihan lingkungan kerja, dan keamanan terhadap barang milik karyawan.

Stres kerja, beban kerja dan lingkungan kerja merupakan variable penting yang berpengaruh dengan kinerja karyawan.Dalam perkembangannya, stres kerja, beban kerja dan lingkungan kerja harus diperhatikan olehperusahaan untuk membuat karyawan yang bekerja dalam perusahaan tersebutmerasa nyaman dalam bekerja.Dalam menyikapi turnover yang tinggi perludilakukan penilaian kinerja, agar manajemen dapat melihat mana-mana sajakaryawan yang kinerjanya perlu ditingkatkan lewat pelatihan-pelatihan.Dengan begitu beban kerja yang ada pada perusahaan sangatmempengaruhi kinerja karyawan yang dihasilkannya, stres kerja kerja yangtinggi juga merupakan pengaruh pada karyawan yang memegang ganda padapekerjaan yang sebenarnya bukan bagian pekerjaannya, karyawan pun menjaditidak efektif pada melakukan kerjaanya, sebagimana beban kerja dan stres kerjakerja saling berkait dan mempengaruhi perusahaan ini (Hani, 2014).

Handoko (2012) mengungkapkan bahwa secara konseptual beban kerjadapat ditinjau dari selisih energi yang tersedia pada setiap pekerjaan denganenergi yang diperlukan untuk mengerjakan sesuatu tugas dengan sukses. Halini berarti beban kerja dapat diubah-ubah, yaitu dinaikkan atau diturunkan,dengan cara mengatur penggunaan energi. Sehingga dapat dikatakan bahwafaktor tugas diberikan disini termasuk faktor situasional.

Selain stres, faktor lain yang mempengaruhi kinerja karyawan adalah lingkungan kerja. Lingkungan kerja yang baik diharapkan dapat memacu kinerja karyawan yang tinggi. Lingkungan kerja yang baik akan sangat besar pengaruhnya terhadap kinerja karyawan, aspek yang berpengaruh terhadap lingkungan kerja antara lain pengaturan penerangan, tingkat kerja, kebisingan, sirkulasi udara yang baik terutama didalam lingkungan kerja, kebersihan lingkungan kerja, dan keamanan terhadap barang milik karyawan.

Lingkungan kerja mempunyai pengaruh terhadap kinerja karyawan perusahaan dalam usaha untuk menyelesaikan tugas-tugas yang dibebankan kapadanya yang akhirnya berpengaruh terhadap produktivitas kinerja karyawan, lingkungan yang baik akan meningkatkan kerja, begitupula sebaliknya apabila lingkungan kerja kurang tenang, akan dapat mempertinggi tingkat kesalahan yang mereka lakukan. Sebuah perusahaan yang beroperasi di sebuah lingkungan tidak dapat menafikan bahwa selain kegiatan bisnis mereka juga terlibat dengan lingkungan disekitar perusahaan, oleh karena itu setiap perusahaan perlu 
memahami secara mendalam mengenai lingkungan apa saja yang terkait secara langsung maupun tidak langsung dengan kegiatan kerjanya sehingga produktivitas pekerja dapat mencapai pada titik yang maksimal.

Lingkungan kerja dalam suatu perusahaan merupakan suatu kondisi pekerjaan untuk memberikan suasana dan situasi kerja karyawan yang nyaman dalam pencapaian tujuan yang diinginkan oleh suatu perusahaan.Kondisi kerja yang buruk berpotensi menjadi penyebab karyawan mudah jatuh sakit, mudah stress, sulit berkonsentrasi dan menurunnya produktivitas kerja. Jika ruangan kerja tidak nyaman, panas, sirkulasi udara kurang memadai, ruangan kerja terlalu padat, lingkungan kerja kurang bersih, berisik, akan berdampak pada kenyamanan kerja karyawan (Mahardiani \& Ari Pradhanawati, 2013).

Stres yang dialami karyawan dan kepuasan kerja yang diinginkan adalah dua kondisi yang bukan saja berkaitan, tetapi sekaligus antagonis.Karena memang adanya perasaan kecemasan antara stres manusia, pekerjaan dan kepuasan.Stres pekerjaan adalah bagian dari stres kehidupan, dan kepuasan kerja adalah sebagian dari kepuasan dalam kehidupan. Stres yang begitu hebat yang melampaui batas-batas toleransi akan merasakan terbebankan oleh pekerjaan yang menjadikan lingkungan kerja menjadi tidak menyenangkan. Oleh karena itu, jika banyak di antara kerja karyawan di perusahaan yang mogok kerja, sering mangkir, atau tidak masuk kerja dengan alasan yang dicari-cari atau kalaupun masuk, tetapi situasi kantor lesu, sering ada konflik dengan pimpinan serta rekan kerja yang lain itulah pertanda lingkungan kerja yang tidak menyenangkan(Sedarmayati, 2009).

Beban kerja yang terlalu berat atau ringan akan berdampak terjadinya in-efisiensi kerja. Beban kerja yang terlalu ringan berarti terjadi kelebihan tenaga kerja. Kelebihan ini menyebabkan organisasi harus menggaji jumlah karyawan lebih banyak dengan produktifitas yang sama sehingga terjadi inefisiensi biaya. Sebaliknya, jika terjadi kekurangan tenaga kerja atau banyaknya pekerjaan dengan jumlah karyawan yang dipekerjakan sedikit, dapat menyebabkan keletihan fisik maupun psikologis bagi karyawan(Astianto, 2015).

Akhirnya karyawan pun menjadi tidak produktif karena terlalu lelah.Beban kerja sangat penting bagi sebuah perusahaan.Dengan pemberian beban kerja yang efektif perusahaan dapat mengetahui sejauh mana karyawannya dapat diberikan beban kerja yang maksimal dan sejauh mana pengaruhnya terhadap kinerja perusahaan itu sendiri.

Lingkungan kerja dalam suatu perusahaan merupakan suatu kondisi pekerjaan untuk memberikan suasana dan situasi kerja karyawan yang nyaman dalam pencapaian tujuan yang diinginkan oleh suatu perusahaan.Kondisi kerja yang buruk berpotensi menjadi penyebab karyawan mudah jatuh sakit, mudah stress, sulit berkonsentrasi dan menurunnya produktivitas kerja. Jika ruangan kerja tidak nyaman, panas, sirkulasi udara kurang memadai, ruangan kerja terlalu padat, lingkungan kerja kurang bersih, berisik, akan berdampak pada kenyamanan kerja karyawan (Mahardiani \& Ari Pradhanawati, 2013)

\section{KAJIAN TEORI}

Menurut Handoko (2012:200) bahwa stres adalah suatukondisi yang mempengaruhi emosi, proses berpikir dan kondisi seseorang.Stres yang terlalu besar dapat mengancam kemampuan seseorang untukmenghadapi lingkungan. Menurut Mangkunegara (2011:157) bahwa stres kerja adalah suatuperasaan tertekan yang dialami karyawan dalam menghadapi pekerjaan

Beban kerja dapat didefinisikan sebagai suatu perbedaan antara kapasitas atau kemampuan pekerja dengan tuntutan pekerjaan yang harus dihadapi.Mengingat kerja manusia bersifat mental dan fisik, maka masing-masing mempunyai tingkat pembebanan yang berbeda-beda. Tingkat pembebanan yang terlalu tinggi memungkinkan pemakaian energi 
yang berlebihan dan terjadi overstress, sebaliknya intensitas pembebanan yang terlalu rendah memungkinkan rasa bosan dan kejenuhan atau understress (Sedarmayati, 2009).

Menurut Nitisemito dalam Nuraini (2013) lingkungan kerjaadalah segala sesuatu yang ada disekitar karyawan dan dapatmempengaruhi dalam menjalankan tugas yang dibebankankepadanya misalnya dengan adanya air conditioner (AC),penerangan yang memadai dan sebagainya. Menurut Isyandi, Lingkungan kerja adalah sesuatu yang ada di lingkungan parapekerja yang dapat mempegaruhi dirinya dalam menjalankantugas seperti temperatur, kelembapan, ventilasi, penerangan,kegaduhan, kebersihan tempat kerja dan memadai tidaknya alatalat perlengkapan kerja Isyandi (2004).

Kinerja adalah hasil atau tingkatan seseorang secara keseluruhan selama periode tertentu selama melaksanakan tugas dibandingkan dengan berbagai kemungkinan, seperti standar hasil kerja, target atau sasaran atau kriteria yang telah ditentukan terlebih dahulu dan telah disepakati bersama (Sudarmanto, 2010). Kinerja merupakan hasil kerja secara kualitas dan kuantitas yang dicapai oleh seorang karyawan dalam melaksanakan tugasnya sesuai dengan tanggung jawab yang diberikan kepadanya (Mangkunegara, 2011).Sedangkan menurut Hasibuan kinerja adalah suatu hasil yang dicapai seseorang dalam melaksanakan tugas-tugas yang dibebankan kepadanya yang didasarkan atas kecakapan, pengalaman, kesungguhan serta waktu (Hasibuan, 2013).

Pengaruh Stres Kerja Terhadap Kinerja Karyawan. Beberapa pendapat menunjukkan bahwa terdapat pengaruh dan hubungan antara stress kerja dan kinerja karyawan. Menurut (Massie, Areros, \& Rumawas, 2018), hasil stres kerja berpengaruh negatif dan signifikan terhadap kinerja karyawan pada Kantor Pengelola IT Center Manado, hal ini menjelaskan bahwa jika stres kerja meningkat maka akan mengurangi potensi kinerja karyawan dan jika sebaliknya stres kerja menurun maka akan meningkatkan potensi kinerja karyawan. Adanya studi yang di lakukan oleh (Wartono, 2017) hasil penelitian menunjukan terdapat pengaruh yang signifikan yang sangat kuat atau positif antara stres kerja terhadap kinerja karyawan yang ditunjukan dengan koefisien korelasi sebesar 0,880 dan koefisien determinasi 77,44\%. Hal ini berarti stres kerja mempengaruhi kinerja sebesar $77,44 \%$ sisanya sebesar $22,56 \%$ dipengaruhi oleh faktorfaktor lain. Setelah dilakukan uji signifikansi didapat hasil 10,643 maka Ho ditolak dan Ha diterima artinya terdapat pengaruh signifikan antara stres kerja terhadap kinerja karyawan.

Pengaruh Beban Kerja Terhadap Kinerja Karyawan. Beberapa pendapat menunjukkan bahwa terdapat pengaruh dan hubungan antara beban kerja dan kinerja karyawan. Menurut (Rolos, Sambul, \& Rumawas, 2018) hasil penelitian, didapat hasil beban kerja berpengaruh negative dan signifikan terhadap kinerja karyawan pada PT. Asuransi Jiwasraya Cabang Manado Kota, hal ini menjelaskan bahwa jika beban kerja meningkat maka akan mengurangi potensi kinerja karyawan dan jika sebaliknya beban kerja menurun maka akan meningkatkan potensi kinerja karyawan, dengan adanya beban kerja seperti system pencapaian target, membuat brosur penjualan sendiri, memberi bimbingan dan pembinaan terhadap calon agen baru sehingga dapat mengurangi potensi kinerja karyawan. Adapun variable dari beban kerja ini berpengaruh sebesar $17,1 \%$ terhadap kinerja karyawan dan ada variabel lain yang tidak diteliti dalam penelitian yang berpengaruh besar terhadap kinerja karyawan pada PT. Asuransi Jiwasraya Cabang Manado Kota.

Pengaruh Lingkungan Kerja Terhadap Kinerja Karyawan.Beberapa pendapat menunjukkan bahwa terdapat pengaruh dan hubungan antara lingkungan kerja dan kinerja karyawan.Menurut (Fariz Ramanda Putra, Hamidah Nayati Utami, \& Muhammad Soe'oed Hakam, 2013) Hasil penelitian ini menunjukan bahwa secara simultan variabel bebas 
lingkungan kerja fisik (X1) dan lingkungan kerja non fisik (X2) berpengaruh signifikan terhadap variabel terikat yaitu kinerja karyawan (Y) yang dapat dilihat dari nilai (sig) $\mathrm{F}<\alpha$ yaitu $0,000<0,05$ serta nilai Adjusted R Square menunjukan angka sebesar 0,524 yang berarti bahwa variabel tersebut memberikan kontribusi sebesar 52,4\% terhadap kinerja karyawan. Secara parsial yang dapat dilihat dari hasil uji t yang menunjukan bahwa variable lingkungan kerja fisik (X1) mempunyai tingkat signifikansi $0,165<0,05$. Sedangkan variabel lingkungan kerja non fisik (X2) mempunyai tingkat signifikansi 0,338. Berdasarkan perhitungan tersebut, dapat disimpulkan bahwa secara parsial lingkungan kerja fisik (X1) dan lingkungan kerja non fisik (X2) memiliki pengaruh signifikan terhadap kinerja karyawan (Y). Sementara itu, analisis deskriptif menunjukan bahwa dengan lingkungan kerja yang berada pada tingkat kuat, didapatkan kinerja karyawan yang kuat pula.

Adanya studi yang di lakukan oleh (Rahmawanti, Swasto, \& Arik Prasetya, 2014) Hasil penelitian ini menunjukkan bahwa berdasarkan analisis deskriptif menunjukkan bahwa mayoritas responden menyetujui lingkungan kerja fisik dan lingkungan kerja non fisik yang ada diperusahaan sudah baik sehingga kinerja karyawan meningkat. Hasil analisis regresi linear berganda menunjukan bahwa secara parsial lingkungan kerja fisik mempunyai pengaruh yang signifikan terhadap kinerja karyawan dan lingkungan kerja non fisik juga mempunyai pengaruh yang signifikan terhadap Kinerja Karyawan. Hasil uji simultan menunjukkan lingkungan kerja fisik dan lingkungan kerja non fisik mempunyai pengaruh yang signifikan terhadap kinerja karyawan.

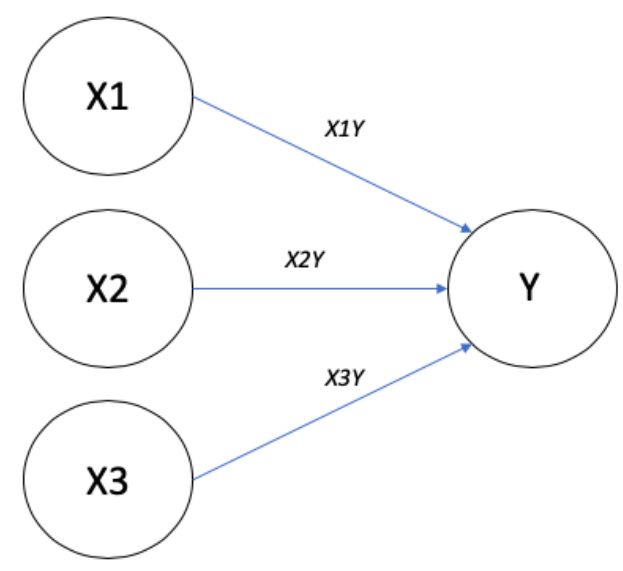

Gambar 1. Kerangka Pemikiran

Berdasarkan kerangka pemikiran diatas maka hipotesis penelitian ini adalah sebagai berikut:

Hipotesis 1 antara variable stress kerja dan kinerja karyawan

Ho1: Setres Kerjaberpengaruhpositif terhadap kinerja Karyawan

Ha1: Setres Kerja tidakberpengaruhpositif terhadap kinerja Karyawan

Hipotesis 2 antara variable beban kerja dan kinerja karyawan

Ho1: Beban Kerjaberpengaruhpositif terhadap kinerja Karyawan

Ha1: Beban Kerja tidakberpengaruhpositif terhadap kinerja Karyawan

Hipotesis 3 antara variable lingkungan kerjadan kinerja karyawan

Ho3:Lingkungan kerja berpengaruhpositif terhadap kinerja karyawan

Ha3:Lingkungan kerja tidak berpengaruhpositif terhadap kinerja karyawan 


\section{METODOLOGI}

Dalam penelitian ini peneliti menggunakan metode kuantitatif . Dalam penelitian ini peneliti mengambil sampel berdasarkan perhitungan Disproporsional Sampel, yaitu jumlah sampel yang diambil dari setiap strata jumlahnya sama tidak sebanding dengan jumlah populasi dengan proporsi sampel di setiap strata. Yang menjadi populasi dalam penelitian ini adalah karyawan PT. Jocelyn Anugrah Jaya yang berjumlah divisi produksi, teknologi informasi, marketing, dan purchasing Dalam penelitian ini peneliti memutuskan untuk mengambil 100sampel di PT. Jocelyn Anugrah Jaya sebagai sampel penelitian

\section{HASIL UJI STATISTIK}

Berdasarkan jenis kelamin, dari 100 responden didapat data sebagai berikut: responden dengan jenis kelamin pria sebanyak 49 atau $49 \%$ dan responden dengan jenis kelamin wanita sebanyak 51 atau 51\%. Berdasarkan usia, dari 100 orang responden didapat data sebagai berikut: responden dengan usia kurang dari 25 tahun sebanyak 38 atau 38\%, responden dengan usia 25-35 tahun sebanyak 62 atau 62\%. Berdasarkan pendidikan terakhir, dari lima puluh responden didapat data sebagai berikut: responden dengan pendidikan terakhir SMA sebanyak 48 atau 48\%, responden dengan pendidikan terakhir D3 sebanyak 45 atau 45\%, responden dengan pendidikan terakhir S1 sebanyak 7 atau $7 \%$. berdasarkan lama bekerja, dari lima puluh responden didapat data sebagai berikut: responden dengan lama bekerja 1 tahun sebanyak 32 atau 32\%, responden dengan lama bekerja 1-2 tahun sebanyak 36 atau 36\%, responden dengan lama bekerja lebih dari 3 tahun sebanyak 32 atau 32\%. Berdasarkan penghasilan, dari 100 responden didapat data sebagai berikut: responden dengan penghasilan $<$ 4Juta sebanyak 33 atau 33\%, responden dengan penghasilan 4-8Juta sebanyak 39 atau 39\%, penghasilan > 8 Juta sebanyak 28 atau $28 \%$.

Model yang digunakan untuk menganalisis Stres Kerja (X1), Beban Kerja (X2) dan Lingkungan (X3) terhadap Kinerja Karyawan (Y) adalah analisis regresi linier berganda.

Tabel 1. Analisis Regresi Ganda

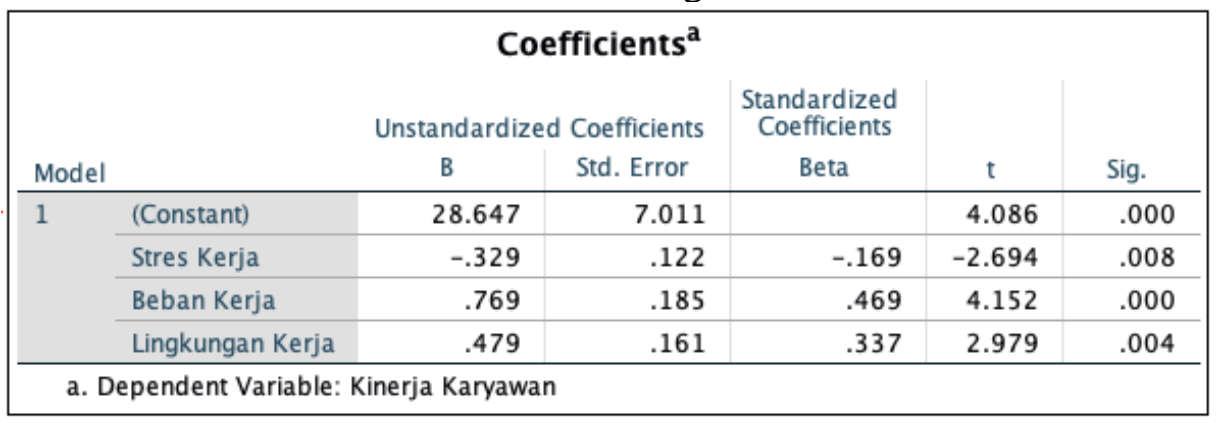

Pada Tabel 1 didapat persamaan regresi linier berganda dengan 3 variabel independen sebagai berikut:

$$
\begin{aligned}
& Y=a+b 1 X 1+b 2 X 2+b 3 X 3+e \\
& Y=28,647+0,113 X 1+0,110 X 2+0,092 X 3+2,236
\end{aligned}
$$




\section{Pengujian Hipotesis}

Untuk mengetahui apakah persamaan tersebut signifikan atau tidak, maka dilakukan pengujian sebagai berikut:

\section{Uji F (ANOVA)}

Uji $\mathrm{F}$ ini dimaksudkan untuk mengetahui ada tidaknya pengaruh dari variabel independen terhadap variabel dependen secara bersama-sama (secara simultan). Berikut adalah hasil uji F dengan bantuan SPSS:

Tabel 2. Hasil Uji Ketepatan Model (Uji F)

\begin{tabular}{|c|c|c|c|c|c|c|}
\hline \multicolumn{7}{|c|}{ ANOVA $^{\mathrm{a}}$} \\
\hline \multicolumn{2}{|c|}{ Model } & $\begin{array}{l}\text { Sum of } \\
\text { Squares }\end{array}$ & df & Mean Square & $\mathrm{F}$ & Sig. \\
\hline \multirow[t]{3}{*}{1} & Regression & 665.542 & 3 & 221.847 & 53.860 & $.000^{\mathrm{b}}$ \\
\hline & Residual & 395.418 & 96 & 4.119 & & \\
\hline & Total & 1060.960 & 99 & & & \\
\hline \multicolumn{7}{|c|}{ a. Dependent Variable: Kinerja Karyawan } \\
\hline \multicolumn{7}{|c|}{ b. Predictors: (Constant), Lingkungan Kerja, Stres Kerja, Beban Kerja } \\
\hline
\end{tabular}

Berdasarkan Tabel 2 dapat dinilai signifikannya adalah 0,00 atau kurang dari alfa 0,05 atau Ho ditolak dan Ha diterima, dan juga $\mathrm{F}$ hitung sebesar 53.860> dari $\mathrm{F}$ table 2,68 maka Ho ditolak, jadi dapat dinyatakan bahwa variabel stres kerja, beban kerja dan lingkugan kerja secara bersama-samaberpengaruh terhadap kinerja karyawan hal ini berarti bahwa model regresi yangdigunakan sudah tepat.

\section{Uji t}

Tabel 3. Hasil Uji Hipotesis T test

\begin{tabular}{|c|c|c|c|c|c|c|}
\hline \multicolumn{7}{|c|}{ Coefficients $^{a}$} \\
\hline & & \multicolumn{2}{|c|}{ Unstandardized Coefficients } & \multirow{2}{*}{$\begin{array}{c}\text { Standardized } \\
\text { Coefficients } \\
\text { Beta }\end{array}$} & \multirow[b]{2}{*}{$\mathrm{t}$} & \multirow[b]{2}{*}{ Sig. } \\
\hline \multicolumn{2}{|c|}{ Model } & B & Std. Error & & & \\
\hline \multirow[t]{4}{*}{1} & (Constant) & 28.647 & 7.011 & & 4.086 & .000 \\
\hline & Stres Kerja & -.329 & .122 & -.169 & -2.694 & .008 \\
\hline & Beban Kerja & .769 & .185 & .469 & 4.152 & .000 \\
\hline & Lingkungan Kerja & .479 & .161 & .337 & 2.979 & .004 \\
\hline
\end{tabular}

a. Hasil pengujian dengan SPSS 25 untuk variabel stres kerja diperoleh nilai thitung = 2,694 lebih besar dari nilai $\mathrm{t}$ tabel 1,984 memiliki probabilitas $0,008>0,05$ artinya signifikan atau dengan kata lain Ha ditolak dan Hoditerima. Kesimpulannya stres kerja secara parsial tidak berpengaruh terhadapkinerja karyawan.

b. Hasil pengujian dengan SPSS 25 untuk variabel Beban kerja diperolehnilai t hitung = 4,152 lebih besar dari nilai $t$ tabel 1,984memilikiprobabilitas $0,000 \leq 0,05$ artinya signifikan atau dengan kata lain Haditerima dan Ho ditolak. Kesimpulannya Beban Kerja secara parsialberpengaruh terhadap kinerja karyawan.

c. Hasil pengujian dengan SPSS 25 untuk variabel gaya Lingkungan Kerjadiperoleh nilai t hitung $=2,979$ lebih besar dari nilai $\mathrm{t}$ tabel 1,980 memilikiprobabilitas $0,04 \leq$ 0,05 artinya signifikan atau dengan kata lain Haditerima dan Ho ditolak. 
Kesimpulannya Lingkungan Kerja secara parsial berpengaruh terhadap kinerja karyawan.

\section{Analisis Koefisien Determinasi $\left(\mathbf{R}^{2}\right)$}

Tabel 4. Tabel Koefisien Determinasi

\begin{tabular}{|l|l|c|c|c|}
\hline \multicolumn{8}{|c|}{ Model Summary } \\
\hline Model & $R$ & R Square & $\begin{array}{c}\text { Adjusted R } \\
\text { Square }\end{array}$ & $\begin{array}{l}\text { Std. Error of } \\
\text { the Estimate }\end{array}$ \\
\hline 1 & $.792^{\text {a }}$ & .627 & .616 & 2.030 \\
\hline \multicolumn{3}{|c|}{$\begin{array}{l}\text { a. Predictors: (Constant), Lingkungan Kerja, Stres Kerja, } \\
\text { Beban Kerja }\end{array}$} \\
\hline
\end{tabular}

Pada Tabel 4 hasil koefisien determinan atau besarnya nilai Adjusted Rsquare (R2) sebesar 0,616 atau 61,6\% yang berarti kontribusi kinerja karyawandapat dijelaskan oleh variabel stres kerja, beban kerja dan lingkungan kerja, namun sisanya 38,4\% dijelaskan oleh variabel-variabel lain yangtidak diteliti dalam penelitian ini.

\section{DISKUSI}

Berdasarkan hasil perhitungan uji t menunjukkan hasil nilai t hitung sebesar-2,694 dan nilai signifikansi sebesar 0,08 lebih besar dari 0,05. Sehingga dapatdisimpulkan bahwa variabel stres kerja tidak berpengaruh positif dan signifikanterhadap kinerja karyawan di divisi komersil Pt. Jocelyn Anugrah Jaya. Hal inimenunjukkan bahwa stres kerja yang dialami oleh karyawan dapatmempengaruhi kinerja mereka. Semakin meningkat stres kerja yang mereka alamitidak terlalu berpengaruh terhadap peningkatan kinerja mereka. Hasil penelitian ini sejalan dengan penelitian-penelitian sebelumnya yangdilakukan oleh Nasyadi Nilamsar Noor et al.(2016), Ella Jauvani Sagala etal.(2017), mereka menemukan bahwa stres kerja tidak berpengaruh positif dantidak signifikan terhadap kinerja karyawan.

Berdasarkan hasil perhitungan uji t menunjukkan hasil nilai t hitung sebesar 4.152dan nilai signifikansi sebesar 0,00 lebih kecildari 0,05. Berdasarkan hasil pengujian Beban Kerja, beban kerja berpengaruh secara signifikan terhadap produktivitas kerja karena mempunyai Sig < 0,05. Berpengaruhsignifikan berarti beban kerja berperan dalam kinerja karyawan.Hubungan antara beban kerja terhadap kinerja karyawan juga positif yang menandakan semakin baik beban kerja, maka Kinerja Karyawan semakin meningkat. Sebaliknya beban kerja yang semakin buruk akan membuat produktivitas semakin menurun. Hasil penelitian ini juga di dukung oleh penelitian yang dilakukan Murti (2013) bahwa beban kerja berpengaruh positif terhadap produktivitas kerja.Penelitian Annisa (2013) beban kerja berpengaruh positif dan signifikan terhadap produktivitas kerja.Penelitian Kurniawan (2016) beban kerja berpengaruhsignifikan terhadap produktivitas kerja.Menurut penelitian Widodo (2014) bebankerja berpengaruh positif dan signifikan terhadap produktivitas kerja.PenelitianMarvidiantika (2014) beban kerja berpengaruh positif dan signifikan terhadapproduktivitas kerja karyawan PT. Wahana Persada Lampung.

Berdasarkan hasil perhitungan uji t menunjukkan hasil nilai t hitung sebesar2,979 dan nilai signifikansi sebesar 0,04 lebih kecil dari 0,05. Sehingga dapatdisimpulkan bahwa variabel lingkungan kerja berpengaruh searah terhadap kinerjakaryawan, yang berarti setiap peningkatan lingkungan kerja yang ada di divisikomersil Pt. Jocelyn Anugrah Jayaakan 
menyebabkan peningkatan kinerjakaryawan secara positif dan signifikan. Lingkungan kerja yang ideal dan kondusif,baik lingkungan kerja fisik maupun non fisik, akan berpengaruh terhadap kinerjapegawai. Lingkungan kerja yang baik dan menyenangkan dapat meningkatkangairah dan semangat kerja dalam perusahaan juga akan mendorong para karyawanuntuk bekerja secara maksimal, sehingga proses dan hasil kerja karyawan akanberjalan baik yang pada akhirnya berpengaruh terhadap peningkatan kinerjakaryawan. Hasil penelitian ini sejalan dengan penelitian-penelitian sebelumnya yangdilakukan oleh Gitahi Njenga Samson et al. (2015), Ferry Moulana et al.(2017),mereka menemukan bahwa lingkungan kerja berpengaruh positif dan signifikanterhadap kinerja karyawan. Hasil penelitian ini sesuai dengan fenomena yangterjadi di Pt. Jocelyn Anugrah Jaya.

\section{KESIMPULAN}

Berdasarkan penelitian dan pembahasan, maka dapat diambil beberapa kesimpulan sebagai berikut:

1. Stres kerja berpengaruh negative dan tidak signifikan terhadap kinerja karyawan di Pt. Jocelyn Anugrah Jaya. Hal ini menunjukan bahwa semakin bertambahnya tingkat stres kerja justru tidak terlalu terjadi peningkatan pada kinerja karyawan.

2. Lingkungan kerja berpengaruh positif dan signifikan terhadap kinerja karyawan khususnya kinerja karyawan Pt. Jocelyn Anugrah Jaya. Hal ini menunjukan bahwa lingkungan kerja yang baik akan berdampak positif terhadap kinerja karyawan.

3. Beban Kerja berpengaruh positif dan signifikan terhadap kinerja karyawan khususnya kinerja karyawan di Pt. Jocelyn Anugrah Jaya.Hal ini menunjukan bahwa Beban Kerja yang banyakakan berdampak positif terhadap kinerja karyawan.

\section{SARAN}

Setelah meneliti dan mengetahui permasalahan yang ada, maka saran yang dapat diberikan bagi perusahaan dan bagi peneliti lain yaitu:

1. Perusahaan harus memberikan solusi bagaimana agar tingkat stres kerjakaryawan bisa selalu kondusif dan bisa dikendalikan dengan baik terutamapada masalah stres kerja yang terdapat pada kuesioner yaitu karyawan yangsering mengalami beban kerja yang sangat tinggi.

2. Perusahaan harus memberikan kelonggaran waktu untuk karyawannya agar bisa beristirahat hai ini di lihat dari bulir pertanyaan "Saya harus selalu bekerja selalu tepat waktu karena sesuai dengan ketentuan perusahaan" Hal itu menunjukkan bahwa karyawan di PT. Jocelyn Anugrah Jaya semuanya harus menyelesaikan pekerjaan tepat waktu sesuai dengan ketentuan perusahaan.

3. Perusahaan harus melengkapi lingkungan fisik yang masih mempunyai kekurangan seperti musik sebagai salah satu hiburan karyawan pada saatmereka beristirahat, hal tersebut akan mampu membantu menghibur karyawan dalam menghilangkan penat.

\section{DAFTAR PUSTAKA}

Astianto, A. (2015). Pengaruh Stres Kerja dan Beban Kerja terhadap Kinerja Karyawan PDAM Surabaya. Urnal Ilmu \& Riset Manajeme, 3(7).

Fariz Ramanda Putra, Hamidah Nayati Utami, \& Muhammad Soe'oed Hakam. (2013). Pengaruh Lingkungan Kerja Terhdap Kinerja (Studi Pada Karyawan PT. Naraya Telematika Malang). Administrasi Bisnis, 6(1).

Handoko, T. H. (2012). Manajemen Personalia dan Sumber Daya Manusia. (19th ed.). 
Yogyakarta: BPFE YOGYAKARTA.

Hani, H. (2014). Manajemen Personalia dan Sumber Daya Manusia (2nd ed.). Yogyakarta: BPFE.

Hasibuan, M. (2013). Manajemen Sumber Daya Manusia (7th ed.). Jakarta: Bumi Aksara.

Mahardiani, Y., \& Ari Pradhanawati. (2013). PENGARUH STRES KERJA DAN LINGKUNGAN KERJA FISIK TERHADAP KINERJA KARYAWAN OUTSOURCINGPADA PT. BANK JATENG CABANG KOORDINATOR DAN CABANG PEMBANTU WILAYAH KOTA SEMARANG. JURNAL ADMINISTRASI BISNIS, 2, 1.

Mangkunegara, P. A. (2011). Manajemen Sumber Daya Manusia. Bandung: Remaja Rosdakarya.

Massie, R. N., Areros, W. A., \& Rumawas, W. (2018). Pengaruh Stres Kerja Terhadap Kinerja Karyawan Pada Kantor Pengelola It Center Manado. Jurnal Administrasi Bisnis, 6(2).

Rolos, J. K. R., Sambul, S. A. P., \& Rumawas, W. (2018). Pengaruh Beban Kerja Terhadap Kinerja Karyawan Pada PT. Asuransi Jiwasraya Cabang Manado Kota. Jurnal Administrasi Bisnis, 6(4).

Sedarmayanti. (2011). Manajemen Sumber Daya Manusia, Reformasi Birokrasi dan Manajemen Pegawai Negeri Sipil (cetakan kelima). Bandung: PT. Refika Aditama.

Sedarmayati. (2009). Tata Kerja dan Produktivitas Kerja. Bandung: Mandar Maju.

Septiana, A., Harini, S., \& Sudarijati, S. (2018). PENGARUH STRES KERJA DAN KEPEMIMPINAN TERHADAP KINERJA KARYAWAN. JURNAL SOSIAL HUMANIORA, 9(1), 34. https://doi.org/10.30997/jsh.v9i1.1377

Sudarmanto. (2010). Kinerja Dan Pengembangan Kompetensi SDM: Teori, Dimensi Pengukuran, Dan Implementasi Dalam Organisasi. Yogyakarta: Pustaka Pelajar.

Wartono, T. (2017). PENGARUH STRES KERJA TERHADAP KINERJA KARYAWAN (STUDI PADA KARYAWAN MAJALAH MOTHER AND BABY). Jurnal Ilmiah Prodi Manajemen Universitas Pamulang, 4(2). 